\title{
Review on Composite Joints for Cold-Formed Steel Structures
}

\author{
Faisal Amsyar ${ }^{1}$, Cher Siang Tan ${ }^{1 *}$, Chau Khun $\mathrm{Ma}^{2}$ and Arizu Sulaiman ${ }^{1}$ \\ ${ }^{1}$ Department of Structure and Materials, Faculty of Civil Engineering, Universiti Teknologi Malaysia, \\ 81310 Johor Bahru, Malaysia \\ ${ }^{2}$ Forensic Engineering Centre, Universiti Teknologi Malaysia, 81310 Johor Bahru, Malaysia
}

\begin{abstract}
Introduction of the lightweight cold-formed steel (CFS) sections to building construction has been well-established these days due to its high structural performance, corrosion resistance, ease of construction and maintenance as well as aesthetic appearance. In the early of $21^{\text {th }}$ century, researchers found out that the structural performance of the CFS can be improved significantly by integrating it with other materials, for instance, concrete, to create the composite system. This is due to concrete material is excellent in compression but less effective to resist tension force. There were little works being carried out and lack of technical literature regarding on the composite connections for CFS structural frames, especially on the composite beam-to-column joints. This paper aims to collect and review on the previous researches of composite joints for CFS structures from the past two decades. The review is made in three distinctive topics i.e. CFS beam-to-column joints, composite beamto-slab joints and composite beam-to-column joints. Most of the investigations indicated that composite joint yields higher ultimate load and moment resistance compared to the non-composite joint.
\end{abstract}

Keywords: cold-formed steel frames, beam-to-column connection, composite joint, moment resistance, initial stiffness, rotational capacity.

\section{Introduction}

At the origin, structural steel is divided into hot-rolled and cold-formed section. Difference in manufacturing process between these steel sections cause to an absolute difference in term of general properties such as strength, structural performance and failure mode [1, 2]. Introduced to the lightweight materials of the CFS sections to the building construction has been well-established these days due to its high structural performance, high corrosion resistance, ease of construction and maintenance as well as aesthetic appearance [2-7]. Several research projects have been carried out by the researchers to study and understand the structural behaviour of CFS members with different connection configurations such as CFS beam-to-column connection, composite beam and floor systems (slab) connection, composite CFS column connection and composite beam-to-column of CFS connection [2, 5] as pictured in Figure 1. Since plenty of research studies that have been done in the early

\footnotetext{
*Corresponding author: tcsiang@utm.my
} 
of $21^{\text {th }}$ century regarding on the CFS members, authors [8-10] found out that the structural performance of the CFS can be improved significantly by integrating it in conjunction with other materials, for instance concrete, to create the composite system. Common ways are to use the cold-formed sections as composite beam in concrete slab systems or composite beam-to-column configurations [8-10].

However, there is only little works and yet lack of technical literature regarding on the composite connections of the CFS especially on the composite beam-to-column of CFS connections. In addition, some researchers [7, 9, 11-19] have mentioned that there is still lack of general design rules for moment connections among the CFS members especially on the composite beam-to-column connections. This paper aims to collect and review on the previous research studies of the CFS connection specifically from the past two decades, since plenty of research studies have been performed and as the significance of CFS is widely concerned. The review is focussed on three connection configurations which are the beam-to-column of CFS connection, composite CFS beam and floor systems (slab) connection and composite beam-to-column of CFS connection. The performance and structural behaviour such as the failure modes, ultimate moment capacity, internal rotation, initial stiffness and ductility of these connections are discussed.

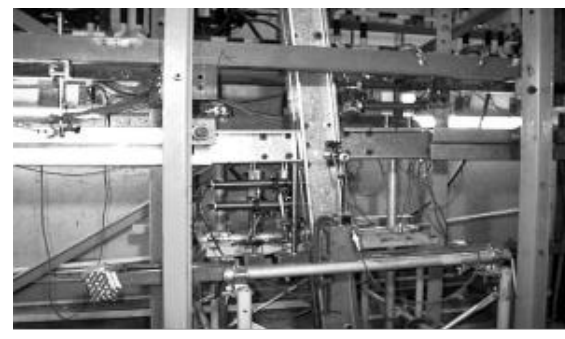

CFS beam-to-column connection (Wong \& Chung, 2002)

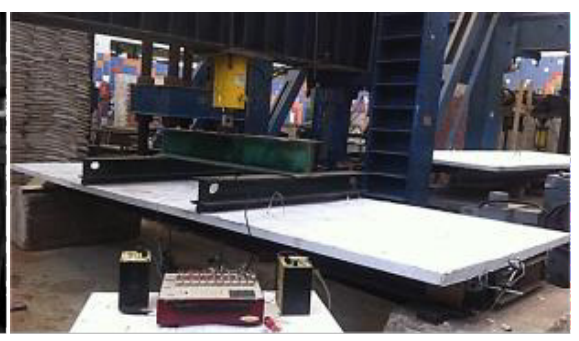

Composite CFS beam-concrete slab connection (Alhajri et al., 2016)

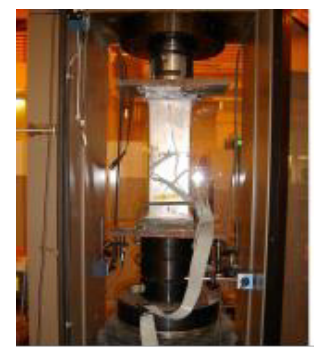

Composite CFS column connection (Young \& Ellobody, 2017)
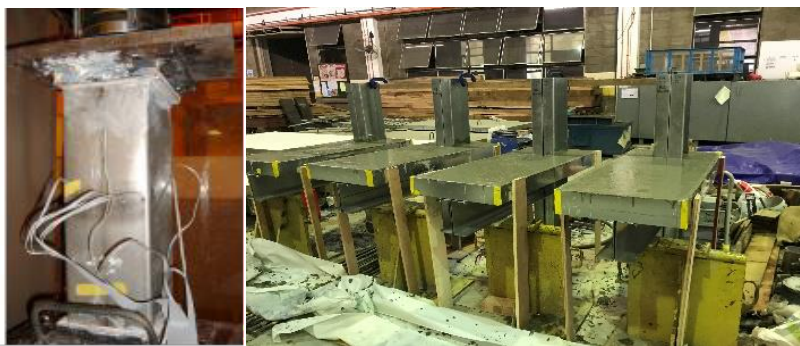

Composite beam-to-column of CFS connection

Figure 1. Types of CFS connection configurations

\section{Cold-formed steel beam-to-column joints}

Tremendous of research studies have been done on the beam-to-column of CFS connection lately and it was considered as well established in the construction fields since it is mainly used in CFS portal frame constructions. Back to 1996, Tan [20] has studied on the nonlinear behaviour of cold-formed thin-walled frameworks with semi-rigid connections through the experimental and mathematical model. Tan [20] stated that as the thickness of the CFS members increase with the increment of the connector thickness, the ultimate failure load was significantly increased. In the findings, Tan [20] also mentioned that all the 
tested connections exhibited for a non-linear moment-rotation behaviour, with the stiffness increasing as the moment decreased largely due to the increasing in flexural rigidity of the connection.

Expending the understandings of beam-to-column for CFS connections, Dubina \& Zaharia [21] suggested that a special importance must be given to the modelling of the bolt zone (local behaviour of connection) and it was mentioned that local analysis of bolt behaviour is required by considering different bolt configurations and different stress states. According to some authors [7, 9, 13-14, 21-24], the ultimate strength of the structure does not significantly influence by the slippage of the bolts which may have some effects on deflection. In 1999, Chung \& Lau [13] found out that strong moment connection with a moment resistance over $50 \%$ of the moment capacity of the connected members is formed by the column base connections that consist of 4 bolts, throughout the experiments. Furthermore, over $80 \%$ of the ultimate moment capacity was found in the specimens that used haunched (modified) gusset plates connector compared to the rectangular and triangular shapes which is only up to $52 \%$ of the moment capacity [13].

Chung \& Lawson [7] have conducted an experimental test based on three different types of fasteners for a total of 24 connection tests with four different connection configurations and concluded that CFS web cleats may be used with the bolts or self-drilling screws fasteners as practical shear resisting connections in building construction by allowing simple and effective connections to improve buildability. Conducting further investigations on the beam-to-column of CFS connection, Wong \& Chung [14] again performed three different types of test series (A, B1 \& B2) on a total of 20 specimens tested under lateral loads in order to assess the strength and stiffness of the connections with different configurations in practical member orientations. Wong \& Chung [7, 13-14] identified that higher moment resistance is shown by the specimens with thicker gusset plates as then the flexural failure in the connected CFS sections become critical instead of the proposed connectors.

Bajoria \& Talikoti [25] have conducted a new test to determine the flexibility of beamto-column connector used in the conventional pallet racking systems. In the investigation, Bajoria \& Talikoti [25] mentioned that double cantilever test is a better representation for the shear to moment ratio in an actual frame rather than the conventional method and this is further confirmed with the full-scale frame test same along with the finite element analysis. To support the development of design provisions for a lateral load-resisting system in the AISI S110: Standard for Seismic Design of Cold-Formed Steel Structural Systems - Special Bolted Moment Frames, Sato [26] has discovered that nine (9) tested specimens of fullscale beam-to-column moment connection subassemblies had interstory drift capacity significantly larger than $0.04 \mathrm{rad}$. However, Sato [26] has mentioned that for the future study, both beams and columns need to be designed in accordance with the capacity design principles and an analytical model for the yielding element is needed to calculate the maximum seismic effect in the non-yielding elements at the design story drift level.

In 2011, Tan [27] has conducted the experimental tests under a single axial compression load with the cantilever arrangement and not subjected to other relevant loads that might compromise the strength and deformation of the connections. Throughout the experiments, Tan [27] analyzed that moment resistance strength of the joint was ranging from 25 to less than $100 \%$ of the moment resistance strength of the connected beam. By general, Tan [27] considered that all specimens as ductile connections since the ductility of the specimens are more than $30 \mathrm{mRad}$, and classified as partial strength connection due to the rotational stiffness improved significantly from 511 to $1671 \mathrm{kNm} / \mathrm{rad}$. The termed of partial strength connection as indicated in the Eurocode 3 can be fulfilled if and only if the connection having a moment resistance of joint less than the moment resistance of the connected beam 
$[1,12,18,27-28]$. Table 1 below depicts the summary on the other previous studies regarding on the beam-to-column of CFS connection. 


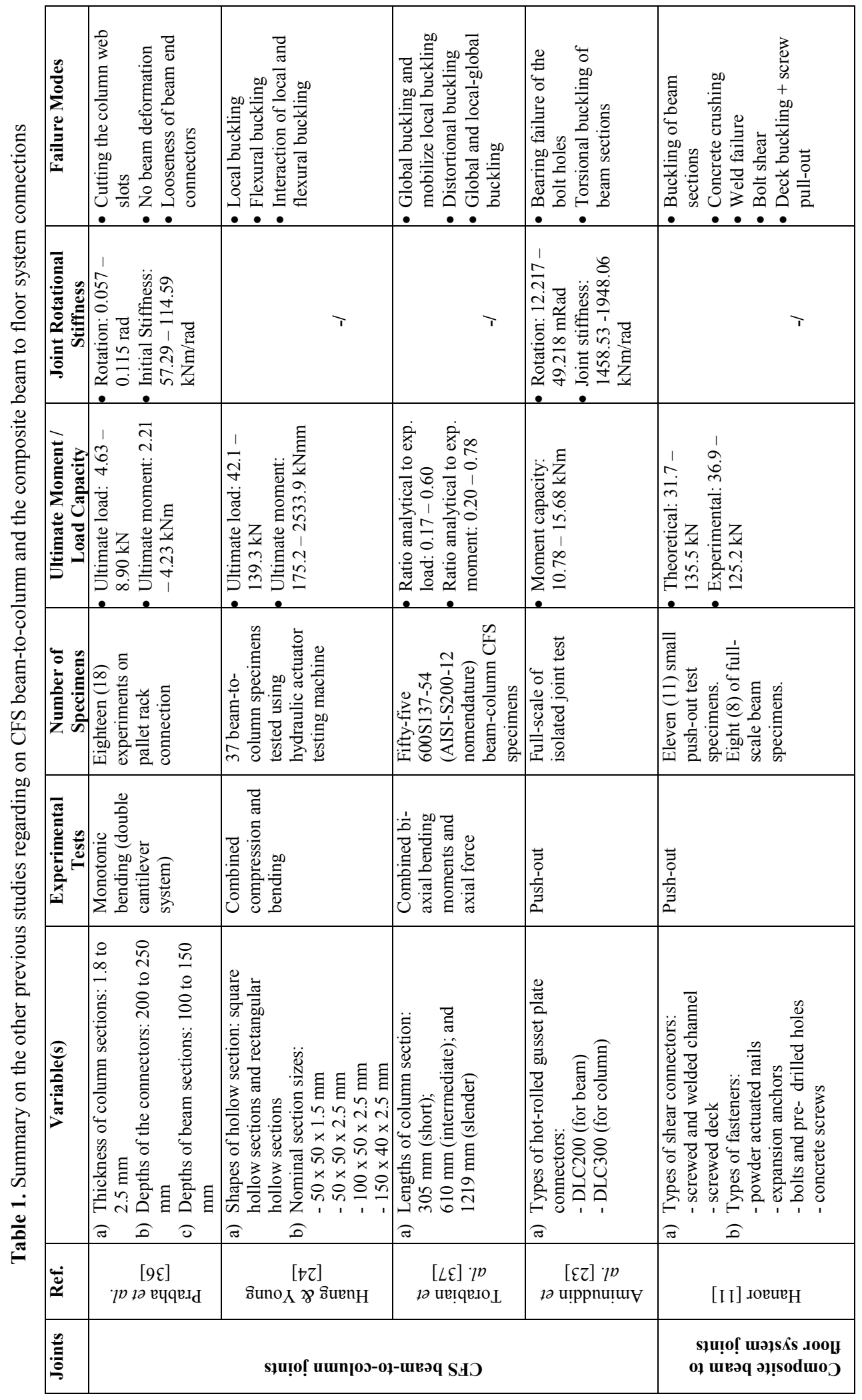




\begin{tabular}{|c|c|c|c|c|}
\hline 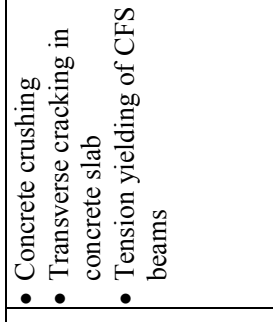 & 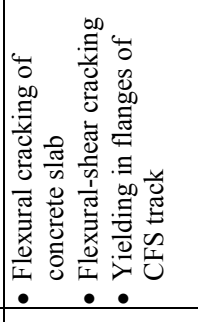 & 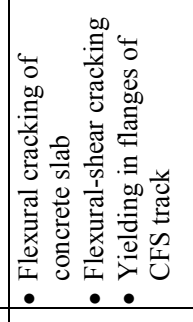 & 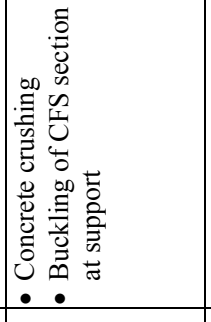 & 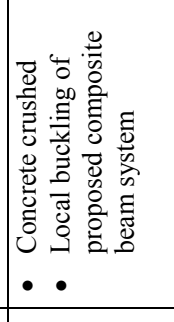 \\
\hline$T$ & 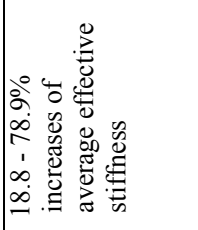 & 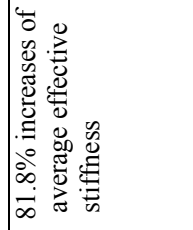 & $T$ & $T$ \\
\hline 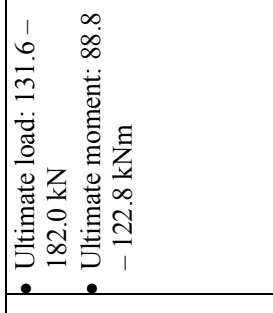 & 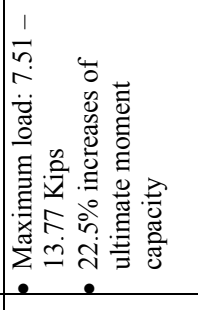 & 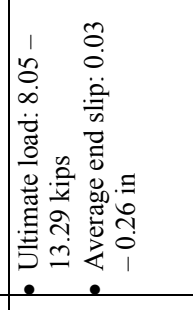 & 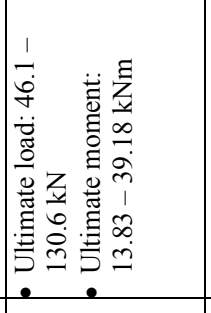 & 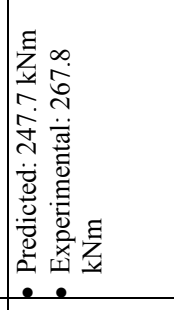 \\
\hline 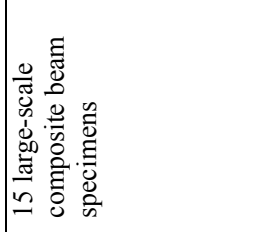 & 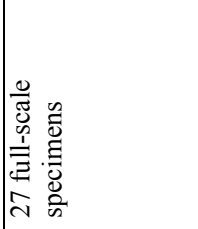 & 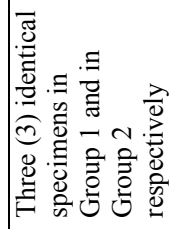 & 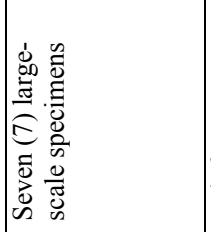 & 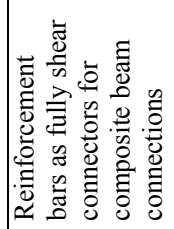 \\
\hline 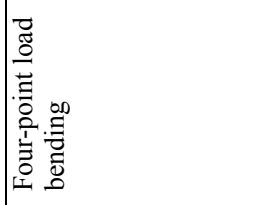 & 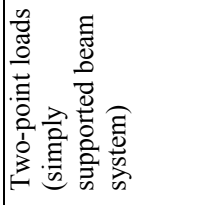 & 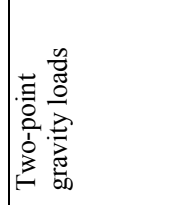 & 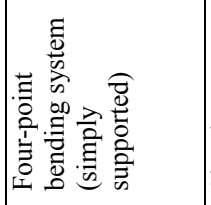 & 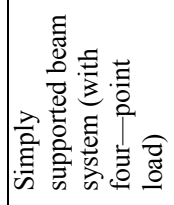 \\
\hline 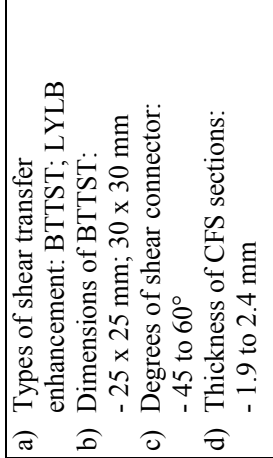 & 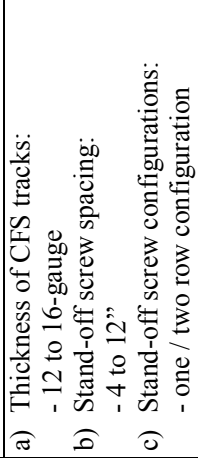 & 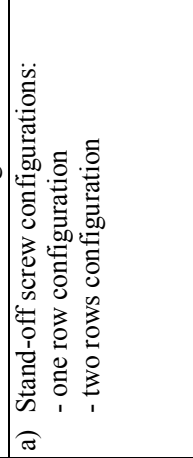 & 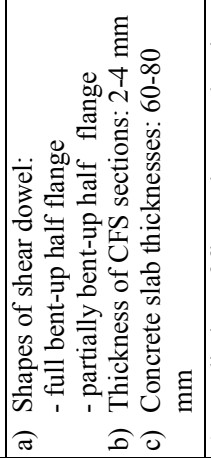 & 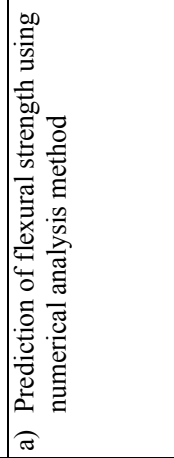 \\
\hline [6] $\eta^{p} \not \partial$ ивм.ІІ & $\begin{array}{c}{[L \mathrm{I}]} \\
\eta^{p} \text { ұә әччәм }\end{array}$ & $\begin{array}{c}{[S I]} \\
\eta^{p ~ д ә ~ ә q ч ว м}\end{array}$ & $\begin{array}{c}{[8 \varepsilon]} \\
p^{p \not \partial \operatorname{suno}_{X}}\end{array}$ & 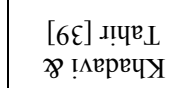 \\
\hline
\end{tabular}




\section{Composite cold-formed steel beam-to-slab joints}

Early in $21^{\text {st }}$ century, many researchers were actively doing research study on the composite steel beam with floor systems (slab), by considering the CFS sections as part of the structural members. Ensuring for adequate shear transfer between the concrete slab and beam sections of CFS connection is one of the common problem in implementing the designs [11]. According to Hsu [29], the key success of an efficient composite system comes from an innovative shear connector, fasteners and the strength of the CFS joists. Initiated by Nguyen [16] in 1991, shear and bending tests on 32 full-size beam specimens under simply supported condition have been run experimentally and found out that good agreement was obtained between the tested and computed shear-bond strength of the beam members within $\pm 15 \%$ of the tested values [16]. To develop a new composite design, Malite [30] has conducted an experimental analysis of the load-slip behaviour and strength of the composite beam with floor systems and it can be observed that in the case of plate thickness, connectors are able to resist the composite action that occurred between the concrete slab and CFS as the thickness of the connectors increased. By continuing further study on composite beam of CFS double channel sections with concrete slab, Malite [31] again carried out a theoretical and experimental investigation to assess the structural behaviour of the composite joint by means of shear connectors constituted of CFS shapes (channel and angle connectors). It can be concluded that the theoretical values obtained based on the initiation of yielding of the section were below $30 \%$ in average of experimental values of the ultimate moment for all tested composite beams [31].

In 2006, there was an idea proposed by Lakkavalli \& Liu [32] to investigate the use of lightweight concrete and high-performance concrete for the structural slab of the composite connections. The idea is that to reduce the thickness and self-weight of the composite beam with the concrete slab. Based on the observations, providing bent-up tabs of shear transfer enhancement enabled to achieve a higher ultimate capacity of the specimens by $17 \%$ with greater stiffness, resulting in lower vertical deflection and significantly reduced slip at the interface, compared to the specimens that relying only in a natural bond between steel and concrete. According to Lakkavalli \& Liu [32], it can be concluded that increase the thickness of the cold-formed C-sections will significantly provide $43.5 \%$ higher in ultimate capacity of the composite CFS beam-concrete slab. The design of the composite connections could be enhanced significantly by depending on the ductile behaviour of the shear connectors and being satisfied with the requirement of EN1994-1-1 standard [18]. Alhajri [19] and Bamaga [18] confirmed that CFS sections and concrete slabs could act compositely perfect if the criteria of the shear connections meet the composite requirements in terms of type, shape, spacing and configuration and in line with the thickness of the CFS sections. To investigate the ductility and strength capacity of the new shear connector for the composite connection, Bamaga [18] has introduced two types of shear connectors which are ' $\mathrm{SC} 1$ ' and 'SC2' shear connectors to run on the push test specimens using DARTEC jack machine with maximum capacity of $1000 \mathrm{kN}$ and tested according to the EN1994-1-1 standard. In the findings, Bamaga [18] found out that the normalized ultimate strength capacity of ' $\mathrm{SC} 2$ ' is slightly higher than ' $\mathrm{SC} 1$ ' shear connector due to the end bearing area of ' $\mathrm{SC} 2$ ' shear connector is larger compared to the ' $\mathrm{SC} 1$ ' connector.

By proposing an analysis and new design procedures of composite section based on some modifications in the AISC Specification (2010), Hsu [29] has conducted experimental tests under flexural bending of four-point loading to a total of six (6) half-scale structural composite beam specimens. In its findings, Hsu [29] discovered that the ultimate strength and ductility of the proposed composite sections were increased by $14-38 \%$ and $56-80 \%$ respectively, as compared to the non-composite sections or built-up sections. A better continuity of slip behaviour can be shown by the proposed composite section rather than 
the non-composite which basically allows the fasteners to well adjust their position. In the era of the composite construction, researchers found out that there is still lack of guidelines on the design of the transverse reinforcing bars for the concrete slab and the optimum slab thickness of the composite section [9-12, 15-19]. A total of six 12-ft long composite beam tests have been carried out by Hsu [22] under four-point loading to induce bending moment. It was found that the specimens with the transverse bars in the concrete slab exhibited higher concrete strength for the composite connections compared to the specimens with no installation of transverse bars in the concrete slab. The ductility of the structure was increased by $80 \%$ and the loading capacity increased by $38 \%$, while the midspan deflection at maximum load was significantly increased.

Since Alhajri [19] has invented a new system called precast U-shaped composite beam produced from the lipped channel sections of CFS connected to the ferro-cement composite slab, Saggaff [12] has further the investigation in 2015 by selecting the best available shear connector and established the performance of the proposed shear connector for the potential pre-cast composite beam of cold-formed-ferrocement slab. The load capacity of shear connector will not significantly improve by increasing the number of layers of wire mesh in the ferro-cement slab [12, 19, 23, 33]. Ten (10) specimens of CFS lipped channel sections connected with ferrocement slab were carried out by Saggaff [12] through the push-out test in order to evaluate the behaviour of different types of shear connectors. The concrete slab acts in compression whereas the CFS section itself acts in tension if and only if suitable shear connector being used to attach the concrete slab to the CFS section [19]. Table 1 above depicts the summary on the other previous studies regarding on the composite beam to floor systems of CFS connection.

\section{Composite cold-formed steel beam-to-column joints}

Recently, it has been proven that composite beam-to-column connection is significant in both economically and structurally, due to its importance to all constructions in enabling to minimize the connection costs as well as instant improvement in the connection quality [34]. Since the CFS is considered as one of the most developed and reliable as an alternative material for wood and hot-rolled steel, tremendous of research works and implementations have been done especially on the beam-to-column and composite beam with the floor systems (slab) of the CFS [11-23]. However, Firdaus [33] and Sulaiman [35] argued that there is still lack of investigation on the composite beam-to-column of the CFS connection. Believing in that, it could be more effective when the CFS members being used in conjunctions with other materials such as the concrete slab. However, the main problem in implementing the composite design is that to ensure sufficient shear transfer between the concrete slab and the CFS section, whereby the thinness of the CFS section is a big challenge that must be faced by the designers and researchers [35].

In the early of 2000, Calado [34] has investigated the S235 JR for the composite beamto-column connections to analyze the influence of the composite slab, the internal and external localization of the joint and the type of the column, steel and composite. According to Calado [34], the deformation of the shear connectors and consequent slip between the composite slab and the steel beam are the main contributions of the strength degradation even though the experimental tests have been performed on specimens' representative of frame structure beam-to-column joints close to the ones typical of Eurocode design practice.

To initiate, propose and model an innovative connection for the CFS beam-column joint, Firdaus [33] has conducted a simple experimental test for the composite beam-tocolumn connection under unrestrained condition with fixed supported at the composite base 
to verify the modelling through finite element analysis. Firdaus [33] found out that the proposed composite connection contributes to the significant increases of the moment capacity and the bolt hole of the beam exhibited for a maximum stress concentration with a value of $503 \mathrm{MPa}$. In the findings, Firdaus [33] concluded that concrete material excellent in compression but unable to resist the direct tension, which is in the tension zone, the connection resistance is provided by anchor reinforcement located at the upper part of the steel connection. Recent study in 2017, Sulaiman [35] has carried out an experimental investigation of composite beam-to-column joint formed by the grade $\mathrm{C} 25$ concrete slab and two lipped CFS C-sections assembled back-to-back as beam and column sections. Sulaiman [35] concluded that the composite joint yields higher ultimate load and moment resistance compared to the non-composite joint since the arrangement of the reinforcements in the composite joint was installed continuous to the back of the column section.

\section{Conclusions}

The structural use of CFS in construction continually growing rapidly across the world exceeded that for the other types of steel structural members. There are some gaps of knowledge that are needed to be filled on the design codes and standards for the composite beam-to-column of CFS connections as it became a new area of study. This could be completed with the comprehensive future research based on the experimental and numerical approach. This review is initiated to summarize research studies on CFS connections. The work is limited by the scopes of discussion as well as the length of the publication. There are several other research projects that are worth to be discussed.

This research was funded by research grant from Universiti Teknologi Malaysia (Grant no.: 13H37 and 03G55) and Ministry of Higher Education Malaysia (MOHE, Grant no.: 4F834). The supports are gratefully acknowledged.

\section{References}

1. Lee, H.Y., Tan, C.S., Mohammad, S., Tahir, M.M., and Shek, P.N. Review on Cold-Formed Steel Connections. The Scientific World Journal. 14, 1-12 (2014)

2. Bucmys, Z., and Sauciuvenas, G. The Behaviour of Cold Formed Steel Structure Connections. Engineering Structures and Technologies. 5(3), 113-122 (2013)

3. Bayan, A., Sariffuddin, S., and Hanim, O. Cold Formed Steel Joints and Structures - A Review. International Journal of Civil and Structural Engineering. 2(2), 1-14 (2011)

4. Lawan, M.M., Tahir, M.M., Ngian, S.P., and Sulaiman, A. Structural Performance of Cold-Formed Steel Section in Composite Structures: A Review. Jurnal Teknologi. 74(4), 165-175 (2015)

5. Yu, W.K., Chung, K.F., and Wong, M.F. Analysis of Bolted Moment Connections in Cold-Formed Steel Beam-Column Sub-frames. Journal of Constructional Steel Research. 61, 1332-1352 (2005)

6. Oguejiofor, E.C., and Hosain, M.U. Behaviour of Perfobond Rib Shear Connectors in Composite Beams: Full-size Tests. Journal of Civil Engineering. 19, 224-235 (1992)

7. Chung, K.F., and Lawson, R.M. Structural Performance of Shear Resisting Connections Between Cold-formed Steel Sections Using Web Cleats of Coldformed Steel Strip. Engineering Structures. 22, 1350-1366 (2000) 
8. Irwan, J.M., Hanizah, A.H., Azmi, I., and Koh, H.B. Large-scale Test of Symmetric Cold-formed Steel (CFS) - Concrete Composite Beams with BTTST Enhancement. Journal of Constructional Steel Research. 67, 720-726 (2011)

9. Irwan, J.M., Hanizah, A.H., and Azmi, I. Test of Shear Transfer Enhancement in Symmetric Cold-formed Steel-Concrete Composite Beams. Journal of Constructional Steel Research. 65, 2087-2098 (2009)

10. Odrobinak, J., Idunk, R., and Bacinsky, T. Study on Stiffness of Composite Beamto-Column Joints. Procedia Engineering. 91, 268-273 (2014)

11. Hanaor, A. Tests of Composite Beams with Cold-formed Sections. Journal of Constructional Steel Research. 54, 245-264 (2000)

12. Saggaff, A., Alhajri, T., Tahir, M.M., Alenezi, K., Tan, C.S., Sulaiman, A., Lawan, M.M., and Ragaee, M. Experimental and Analytical Study of Various Shear Connectors Used for Cold-formed Steel-Ferrocement Composite Beam. Applied Mechanics and Materials. Vols. 754-755, 315-319 (2015)

13. Chung, K.F., and Lau, L. Experimental Investigation on Bolted Moment Connections Among Cold Formed Steel Members. Engineering Structures. 21, 898-911 (1999)

14. Wong, M.F., and Chung, K.F. Structural Behaviour of Bolted Moment Connections in Cold-formed Steel Beam-Column Sub-frames. Journal of Constructional Steel Research. 58, 253-274 (2002)

15. Wehbe, N., Bahmani, P., and Wehbe, A. Behavior of Concrete/Cold Formed Steel Composite Beams: Experimental Development of A Novel Structural System. International Journal of Concrete Structures and Materials. 7(1), 51-59 (2013)

16. Nguyen, R.P., and ASCE. Thin-walled, Cold-formed Steel Composite Beams. Journal of Structural Engineering. 117(10), 2936-2952 (1991)

17. Wehbe, N., Wehbe, A., Dayton, L., and Sigl, A. Development of Concrete/Cold Formed Steel Composite Flexural Members. Structures Congress. 605, 3099-3109 (2011)

18. Bamaga, S.O., Tahir, M.M., and Tan, C.S. Push Tests on Innovative Shear Connector for Composite Beam with Cold-formed Steel Section. $21^{\text {st }}$ International Specialty Conference on Cold-Formed Steel Structures. 1, 327-339 (2012)

19. Alhajri, T.M., Tahir, M.M., Azimi, M., Mirza, J., Lawan, M.M., Alenezi, K.K., and Ragaee, M.B. Behavior of Pre-cast U-Shaped Composite Beam Integrating Cold-formed Steel with Ferro-cement Slab. Thin-Walled Structures. 102, 18-29 (2016)

20. Tan, S.H., Seah, L.K., and Fok, S.C. Connections in Cold-formed Thin-Walled Structures. Computers \& Structures. 60(1), 169-172 (1996)

21. Dubina, D., and Zaharia, R. Cold-formed Steel Trusses with Semi-Rigid Joints. Thin-Walled Structures. 29, 273-287 (1997)

22. Hsu, C.T.T., Punurai, S., Punurai, W., and Majdi, Y. New Composite Beams Having Cold-formed Steel Joists and Concrete Slab. Engineering Structures. 71, $187-200$ (2014)

23. Aminuddin, K.M., Saggaff, A., and Tahir, M.M. Experimental Behaviour of Beam-Column Connection Using Cold-Formed Steel Sections with Rectangular Gusset-Plate. Proceedings of the $3^{\text {rd }}$ International Conference on Construction and Building Engineering (ICONBUILD). 1903, 1-7 (2017)

24. Huang, Y., and Young, B. Experimental Investigation of Cold-formed Lean Duplex Stainless Steel Beam-Columns. Thin-Walled Structures. 76, 105-117 (2014) 
25. Bajoria, K.M., and Talikoti, R.S. Determination of Flexibility of Beam-to-Column Connectors Used in Thin Walled Cold-formed Steel Pallet Racking Systems. ThinWalled Structures. 44, 372-380 (2006)

26. Sato, A., Uang, C.M., Hong, J.K., and Wood, K. Cold-formed Steel Special Bolted Moment Frames Cyclic Testing and Numerical Modelling of Moment Connections. $19^{\text {th }}$ International Specialty Conference on Cold-Formed Steel Structures. 6, 577-589 (2008)

27. Tan, C.S., Tahir, M.M., Shek, P.N., and Ahmad, K. Experimental Investigation on Slip-in Connection for Cold-formed Steel Double Channel Sections. Advanced Materials Research. Vols. 250-253, 1038-1041 (2011)

28. Lee, Y.L., Tan, C.S., Lee, Y.H., Mohammad, S., Tahir, M.M., and Shek, P.N. Effective Steel Area of Fully Embedded Cold-formed Steel Frame in Composite Slab System Under Pure Bending. Applied Mechanics and Materials. Vols. 284287, 1300-1304 (2013)

29. Hsu, C.T.T., Munoz, P.R., Punurai, S., Majdi, Y., and Punurai, W. Behavior of Composite Beams with Cold-formed Steel Joists and Concrete Slab. $21^{\text {st }}$ International Specialty Conference on Cold-Formed Steel Structures. 2, 341-355 (2012)

30. Malite, M., Nimir, W.A., Sales, J.J.D., and Goncalves, R.M. Cold-formed Shear Connectors for Composite Constructions. $14^{\text {th }}$ International Specialty Conference on Cold-Formed Steel Structures. 98, 409-421 (1998)

31. Malite, M., Nimir, W.A., Sales, J.J.D., and Goncalves, R.M. On The Structural Behaviour of Composite Beams Using Cold-formed Shapes. $15^{\text {th }}$ International Specialty Conference on Cold-Formed Steel Structures. 20, 307-319 (2000)

32. Lakkavalli, B.S., and Lui, Y. Experimental Study of Composite Cold-formed Steel C-section Floor Joists. Journal of Constructional Steel Research. 62, 995-1006 (2006)

33. Firdaus, M., Saggaff, A., and Tahir, M.M. Finite Element Analysis of Composite Beam-to-Column Connection with Cold-Formed Steel Section. Proceedings of the $3^{\text {rd }}$ International Conference on Construction and Building Engineering (ICONBUILD). 1903, 1-8 (2017)

34. Calado, L., Simoes da Silva, L., and Simoes, R. Cyclic Behavior of Steel and Composite Beam-to-Column Joints. Connections in Steel Structures IV. Vols. 1-3, 159-169 (2000)

35. Sulaiman, A., Salleh, N.M., Sukardi, N., Tan, C.S., and Saggaff, A. Experimental Evaluation of Composite Beam-to-Column Joint Using Cold-Formed Steel Sections. International Conference on Construction and Building Engineering (ICONBUILD). 1-7 (2017)

36. Prabha, P., Marimuthu, V., Saravanan, M., and Jayachandran, S.A. Evaluation of Connection Flexibility in Cold Formed Steel Racks. Journal of Constructional Steel Research. 66, 863-872 (2010)

37. Torabian, S., Zheng, B., Schafer, B.W. Experimental Response of Cold-formed Steel Lipped Channel Beam-Columns. Thin-Walled Structures. 89, 152-168 (2015)

38. Youns, M.A., Hassaneen, S.A., Badr, M.R., and Salem, E.S. Composite Beams of Cold Formed Steel Section and Concrete Slab. International Journal of Engineering Development and Research. 4(4), 165-177 (2016)

39. Khadavi, and Tahir, M.M. Prediction on Flexural Strength of Encased Composite Beam with Cold-formed Steel Section. Proceedings of the $3^{\text {rd }}$ International Conference on Construction and Building Engineering (ICONBUILD). 16(6), 1-6 (2017) 